\title{
Changes in the horizontal development of phytoplankton of the littoral of Lake Sevan (Armenia) in conditions of water level fluctuations
}

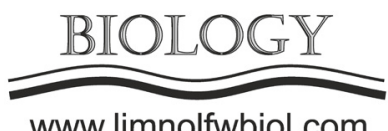

www.limnolfwbiol.com

\author{
Hambaryan L. ${ }^{1,2 *}$, Khachikyan T. ${ }^{1}$, Ghukasyan E. ${ }^{1}$ \\ ${ }^{1}$ Institute of Hydroecology and Ichthyology of the Scientific Centre of Zoology and Hydroecology of NAS, P. Sevak st.7, o014 Yerevan, \\ Armenia \\ ${ }^{2}$ Department of Ecology, Yerevan State University, 8 Charenc str., 0025, Yerevan. RA
}

\begin{abstract}
The study of seasonal dynamics in the horizontal development of phytoplankton is important for the ecological assessment of coastal biotopes of lakes. Water level fluctuations affect the quantitative and qualitative parameters of phytoplankton, that caused bloom in 2019. In the development of phytoplankton, an unpredictable succession was observed at the level of divisions and species of algae, which was expressed by water flowering in different seasons. During the active growing season in Lake Sevan, three quantitative maxima were observed in the development of phytoplankton in the lake. In the spring, green algae reached the level of blooming (88\%), in the summer - cyanobacteria $(90 \%)$ and in the fall - diatoms (80\%). Frequent algal blooms in the littoral zone indicate the presence of pollution, lead to nutrient enrichment, changing climatic conditions. Blooming of water in summer period with toxic species of the genus Dolichospermum/Anabaena are toxic and cause changes in the habitat. CyanoHABs is a danger of the transfer of blooms to the deep-water areas of the lake, as it observed in 2018-19.
\end{abstract}

Keywords: Cyanobacterial water bloom, toxigenic alga, littoral zone, Shannon index, saprobity

\section{Introduction}

Species composition of hydro-biocoenoses carries information about state of water ecosystem and is a part of diversity of the lake. They are distinguished by their belonging to one or other systematic, taxonomic category. Depending on the adaptive capacity of individual species and the environmental state, composition of the communities are involved different species which aggregation is most often referred to as biological (species) diversity (Uzunov and Kovachev, 2002). Phytoplankton taxonomic composition globally includes about 4000-5000 species (Sournia et al., 1991; Tett and Barton, 1995)

The main groups of phytoplankton of Lake Sevan belong to division Bacillariophyta, Cyanophyta, Ghlorophyta and increased in recent yearsEuglenophyta.

\section{Materials and methods}

Water samples were collected from littoral part of Lake Sevan in spring-summer 2019 (Fig. 1).

Water samples collected for phytoplankton study were preserved with $40 \%$ formaldehyde solution and stored in a dark place for 10-12 days. Then, the volume of the sample was decreased from $1000 \mathrm{~mL}$ to $100 \mathrm{~mL}$. By repeating the same process, the volume of the experimental samples was reduced to $10 \mathrm{~mL}$ (Abakumov, 1983). The qualitative and quantitative analyses of phytoplankton were conducted under the microscope in the Nageotte chamber $(\mathrm{V}=0,1 \mathrm{ml})$. Taxonomic groups of phytoplankton were identified by using the keys/determinants (Tsarenko, 1990; Streble and Krauter, 2001; Linne von Berg et al., 2012; Makovinska, 2013; Hambaryan and Shahazizyan, 2014). The diversity status of phytoplankton community in the river ecosystems was assessed by ShannonWiener diversity index (Shannon and Weaver, 1949). The comparative analysis of the phytoplankton species composition of the investigated rivers was performed by Sorensen similarity index (Sorensen, 1948).

Monitoring of the ecological state of the ecosystem of Lake Sevan $(1900 \mathrm{~m})$ is estimated by the hydrobiont communities, which are indicators of trophic state (Hambaryan et al., 2018; Sakharova et al., 2020). Lake Sevan is located in the Gegharkunik Province in eastern part of the Republic of Armenia. The lake is consists of two unequal parts: in Minor Sevan (average depth $50.9 \mathrm{~m}$ ) and Major Sevan (average depth $37.7 \mathrm{~m}$ ). The catchment of lake includes 30 rivers and streams
*Corresponding author.

E-mail address: lus-ham@yandex.ru $\quad$ (L. Hambaryan) lusinehambaryan@ysu.am
(C) Author(s) 2020. This work is distributed under the Creative Commons Attribution 4.0 License. 


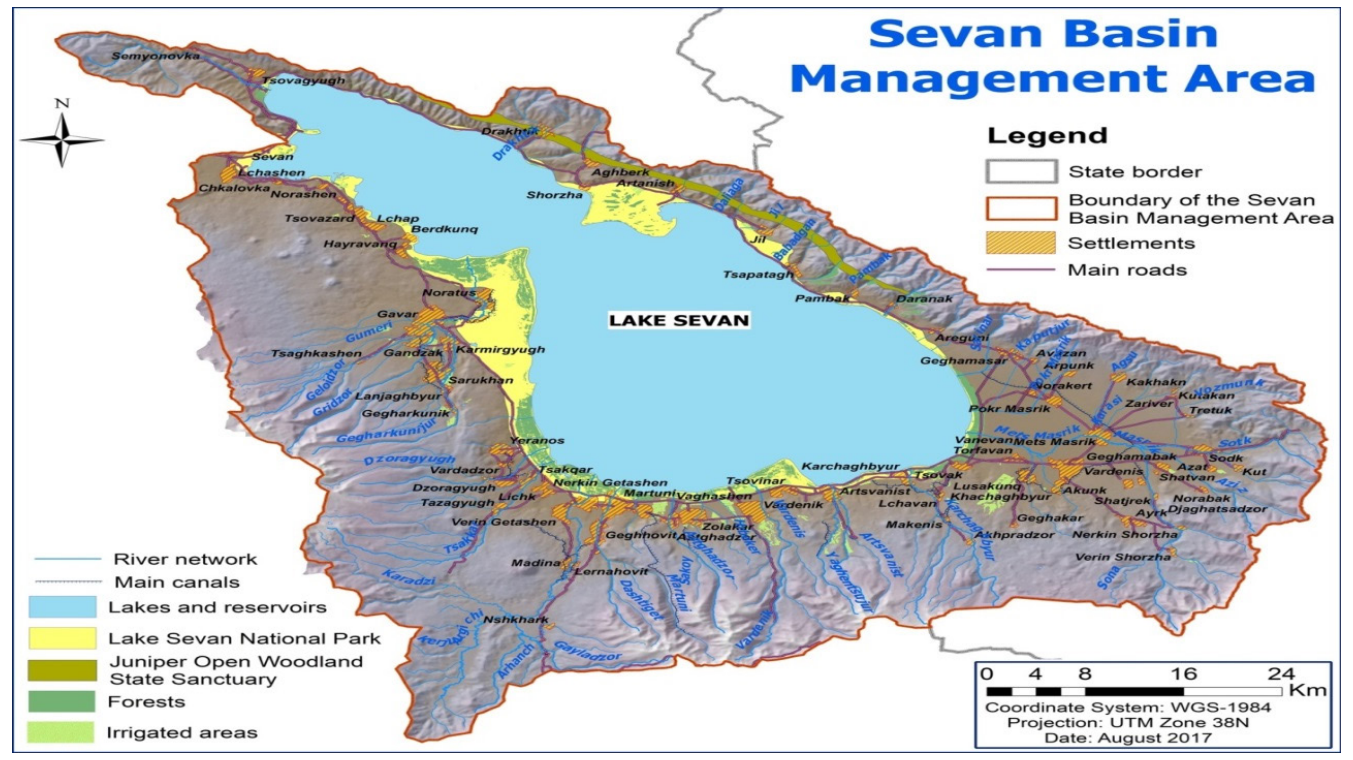

Fig.1. Map of Lake Sevan

flow into Lake Sevan, and the only river flowing out of the lake is Hrazdan (Chilingaryan and Mnacakanyan, 2010).

Studies of the phytoplankton of the littoral zone were started in 2015, as the program to increase the water level led to the formation of new biotopes. High variability of environmental factors and active biogenic enrichment of coastal areas leads to an increase in the biodiversity of these territories; they are sources of the species richness of the reservoir as a whole. The deterioration of the lake, observed over the past 2 years, is due to the intense flowering of Cyanobacteria of the toxigenic genus Dolichospermum/Anabena in the summer. A feature of the development and horizontal distribution of the phytoplankton of Lake Sevan, in 2019 , was the presence of three quantitative peaks in the dynamics caused by increased flowering water. So, in spring, flowering in the littoral, was caused by the green alga Binuclearia lauterbornii, in the summer - the Cyanobacteria Dolichospermum/Anabaena flos-aquae.

During the period of phytoplankton blooms, the species of algae that caused the bloom in Minor Sevan and Major Sevan had high rates in the spring-summer period, the dynamics of the quantity development is shown in Fig 2.
As a result of flowering, changes in water quality indicators are observed: transparency $(0 \mathrm{~m})$, the amount of dissolved oxygen, the $\mathrm{pH}$ of the water - all this affects on the dynamics of the development of aquatic organisms in the food chain, the natural development of which can be suppressed as a result of flowering (Hambaryan et al., 2019).

As a result of the dominance of cyanobacteria and greens, in the spring-summer period, the development of diatoms was suppressed, however, the increase in their quantitative indicators in the autumn period was due to the flowering of the diatom centric alga Cyclotella kuetzingiana. It should be noted that diatoms were persistent dominants of the phytoplankton of the lake in terms of their qualitative characteristics during the period of increasing water after 2001 . The average annual biomass in 2019 was $2.9 \mathrm{~g} / \mathrm{m}^{3}$, in $2018-8 \mathrm{~g} /$ $\mathrm{m}^{3}$. Phytoplankton biomass in 2018 corresponded to eutrophic, and in 2019- the mesotrophic status of lakes. Average annual saprobity indicators in 2019 amounted to 1.9 , the Shannon index was 1.03, indicators for 2018 were: 1.9 and 1.5 , respectively.

The importance of analyzing changes in littoral zone phytoplankton indices, an increase in eutrophication species in plankton and identification of

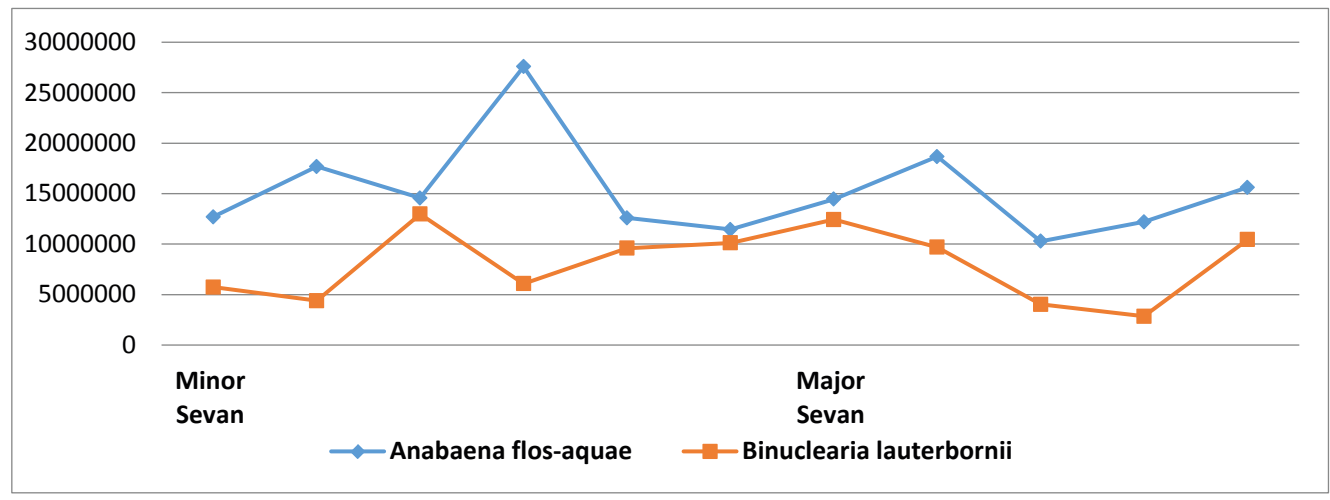

Fig.2. Development dynamics of eutrophication species, that caused water blooms in different seasons of 2019 . 
flowering consequences is important for assessing the water quality and ecological status of Lake Sevan, the largest high-altitude reservoir in the Caucasus.

\section{Acknowledgement}

This research was conducted with the support of "Ecological features of the Lake Sevan bays in terms of water level fluctuations" programme, code 18T-1F278.

\section{References}

Abakumov V.A. 1983. Rukovodstvo po metodam gidrobiologicheskogo analiza poverkhnostnykh vod i donnykh otlozheniy [Guide on methods for the hydrobiological analysis of surface water and bottom sediments]. Leningrad: Gidrometeoizdat. (in Russian)

Chilingaryan L.A., Mnacakanyan B.P. 2010. Hydrology of Lake Sevan: hydrology of Lake Sevan catchment basin. In: Ekologiya ozera Sevan v period povysheniya yego urovnya [Ecology of Lake Sevan during the period of water level rise]. Makhachkala, pp. 14-28. (in Russian)

Sakharova E.G., Krylov A.V., Sabitova R.Z. et al. 2020. Horizontal and vertical distribution of phytoplankton in the alpine Lake Sevan (Armenia) during the summer Cyanoprokaryota bloom. Problems of Ecology 13(1): 60-70. DOI: $10.1134 /$ S1995425520010072

Hambaryan L.R., Stepanyan L.G., Hovhannisyan N.A. et al. 2019. Environmental risks and consequences of flowering of Cyanobacteria in the summer period of the high mountain Lake Sevan (Armenia). In: International Conference "Microbes: Biology\&Application", p. 72.

Hambaryan L., Shahazizyan I. 2014. Determinant and educational manual for genera of freshwater algae. Yerevan: YSU Press. (in Armenian)
Hambaryan L.R., Mamyan A.S., Khachikyan T.G. et al. 2018. Studies of the horizontal distribution of phytoplankton in Lake Sevan (Armenia). In: International Conference "Freshwater Ecosystems - Key Problems", p. 167.

Linne von Berg K.-H., Hoef-Emden K., Melkonian M. 2012. Der Kosmos-Algenführer: Die wichtigsten Süßwasseralgen im Mikroskop [The kosmos algae guide: the most important freshwater algae under the microscope]. Stuttgart: Kosmos. (in German)

Makovinska J. 2013. Manual of quantitative and qualitative monitoring of freshwater phytoplankton community. Yerevan.

Shannon C.E., Weaver W. 1949. The mathematical theory of communication. Urbana: Urbana University Press.

Sournia A., Chrétiennot-Dinet J., Ricard M. 1991. Marine plankton: how many species in the world oceans? Journal of Plankton Research 13: 1093-10999. DOI: 10.1093/ plankt/13.5.1093

Streble H., Krauter D. 2001. Das Leben im Wassertropfen [Life in a drop of water]. Stuttgart: Kosmos. (in German)

Sorensen T. 1948. A method of establishing groups of equal amplitude in plant sociology based on similarity of species content and its application to analyses of the vegetation on Danish commons. Biologiske Skrifter 5: 1-34.

Tett P., Barton E.D. 1995. Why are there about 5000 species of phytoplankton in the sea? Journal of Plankton Research 17: 1693-704. DOI: 10.1093/plankt/17.8.1693

Tsarenko P.M. 1990. Kratkiy opredelitel' khlorokokkovykh vodorosley Ukrainskoy SSR [Brief guide to chlorococcal algae of the Ukrainian SSR]. Kiev: Naukova Dumka. (in Russian)

Uzunov I., Kovachev S. 2002. Hydrobiology. Sofia/ Moscow: Pensoft. (in Bulgarian) 